ISSN 0258-7122 (Print), 2408-8293 (Online)

Bangladesh J. Agril. Res. 41(4): 773-776, December $2016 \quad$ Short Communication

\title{
ICT MANAGEMENT TOOL USES IN AGRICULTURAL EXTENSION SERVICES IN BANGLADESH
}

\author{
K. S. RAHMAN ${ }^{1}$, N. MOHAMMAD ${ }^{2}$, S. NASRIN ${ }^{3}$ \\ S. KUNDU ${ }^{4}$ AND M. M. RAHMAN ${ }^{5}$
}

Keywords: ICT management tool, agricultural extension, digital data, information.

Bangladeshi farmers gain traditional agricultural knowledge and skills by hereditary. Such experience and historic knowledge are now inadequate to meet the food requirement of the huge population of the country. Thus modernization of the traditional system is very essential for the agriculture sector of Bangladesh. This article focuses on the innovations and developments. As such we have given focused on by ICT access in agricultural sector of Bangladesh. Bangladesh is a developing country. Agriculture, being one of the major driving forces is contributing maximum share to the GDP and the growing economy of the country. Almost $80 \%$ of the total workforce directly connected to agriculture (Kashem et al., 2010). Due to the rapid growth of population the food demand is increased. Though the agricultural sector is developing it does not achieve the optimum level due to lack of up to date knowledge and information. Usually the farmers counter difficulties in obtaining the proper information as they collect information from conventional and traditional sources like extension fellow farmers. From season to season there is high demand of up to date information for new cultivation processing techniques, pest and diseases control, marketing and consumer demand, crops transport etc (Malone et al., 2012).

Timely and accurate information can assist farmers to protect from potential seasonal losses. Up to date knowledge can helps them to make optimum use of limited resources. As such the conventional method of cultivation is to be changed using modern digital ICT services.

The Country has stepped into new era of digital world with a spectacular vision for making Digital Bangladesh. This vision would be saddled by e-agriculture involving multi disciplinary initiatives of agricultural information, agricultural development and entrepreneurship towards building a hunger free, efficient and resourceful Bangladesh.

The history of ICT use in Bangladesh agriculture is not so rich. ICT taskforce program launched in 2003 by the ministry of agriculture perhaps would be the first initiative to set up on Agricultural Information system. Recently a dedicated division Agricultural Statistics and Information \& Communication Technology (ASICT) has been established in BARI for providing the agricultural Information

\footnotetext{
${ }^{1 \& 2}$ Scientific Officer, ASICT Division, Bangladesh Agricultural Research Institute (BARI), Gazipur-1701, ${ }^{4}$ Scientific Officer, Planning \& Evaluation Division, BARI, Gazipur-1701, ${ }^{5}$ Scientific Officer, Pulses Research Sub Station, BARI, Gazipur-1701, ${ }^{3}$ M.Sc in Statistics, Rajshahi University, Bangladesh.
} 
services digitally. Since no such studies on database development for ICT uses and e-agriculture have been found for the selected areas, we are intended to develop such a database which could be helpful for the cultivators of the selected region (Qaisar et al., 2011).

\section{Methods to disseminate information}

To harness ICT in Agriculture and rural livelihood a conceptual model of eagriculture has been formulated. e-agriculture is an emerging field focusing on the enhancement of agricultural and rural development through improved information and communication processes. It involves the conceptualization, design, development, evaluation and application of innovative ways to use the rural domain with a primary focus on agriculture.

The information disseminated by e-agriculture can be divided into several major areas, which is called as services of e-agriculture (Dash et al., 2006). These ares-

1. Weather information

2. Price information

3. Production and cultivation techniques

4. Plant nutrients and water usage

5. Education and health information

6. Govt. and non govt. facilities

7. Demand and current stock information

8. Diseases and insect information

\section{Assess to Agricultural Information \& Service delivery:}

\section{a) Broadcasting System:}

Along with the print media, Radio and TV have the most significant role in delivering agricultural information. Radio and TV are mass communication tools those are being used all over the country. Bangladesh Television (BTV) provides agricultural information throughout many agricultural programs and news. Other private channels have their individual programs regarding this aspect. Channel $-\mathrm{I}$ (a private TV Channel) is the pioneer with prominent, regular agricultural programs like Ridoye mati o manush and agricultural news (www.channel-i-tv.com). The popularity of urban, private FM radio stations is on rise especially among the youth but all the radio channels are not accessible all over the country. The good news is that almost all the channels broadcast agricultural programs and news.

\section{b) Mobile Phones and cellulars:}

Almost $98 \%$ of the Bangldesh population uses mobile phone now a days (www.btrc.gov.bd). Mobile phones can play significant role in linking farmers 
and service providers and key stages of the agricultural value chains. Among all the features voice call \& SMS are mostly \& widely used among the farmers. The mobile phone operator has brought a numerous programs and features for farmers. like Jigyasha 7676 helpline by Banglalink. Similar features are also available in other operators like Grameen phone, Robi, Citycell etc. These Programs have added a new dimension in access to information in Agricultural sector. Besides Mobile banking, b-kash, Mobi-cash, e-ticketing by mobile etc. have made the financial and marketing jobs easy for the formers.

Moreover mobile phones now a day have radio features. This combination of mobile phone and radio has become an important tool in information exchange and communication exchange. Combination of TV \& mobile along with internet facility ( $3 \mathrm{G} \mathrm{\&} 4 \mathrm{G}$ ) has become the optimist opportunity for the users to access in formations; though these combined $\&$ aneroid phones are rarely used by the farmers for their high price.

\section{c) Internet Infrastructures and Access :}

Although internet usage in agriculture is new in Bangladesh, it is becoming very popular among the farmers. According to the Bangladesh telecommunication regulatory commission (BTRC) total internet usage of 2013 reached 33.3 million and this done mainly through mobile based internet access. Though broadband connections are still rare outside of major urban areas but the mobile operators provide high speed internet packages now a days like 3G. In rural areas there are some physical information centers which can provide internet services to the farmers. These are like UISC, AICC, Private sector initiatives operated either by NGOs or entrepreneurs.

The recent revolution in the ICT industry, due to massive penetration of mobile phone and digital Bangladesh initiatives contributed significantly to trigger the changes in extension service. Telecom operators contributed in taking the connectivity issue forward. NGOs also play an important role to explore innovative ideas to introduce ICT enabled services. The Bangla typing software which has been recently introduced, in mobile, created a big way in texting \& SMS communications.

\section{Challenges to establish ICT related extension services:}

The challenges can be categorized in roughly three categories-

a) Technology

b) Human Capacity

c) Content

a) Technology: Technology is not an actual challenges but the tool that involves may be considered in some perspective. It may create some 
difficulties when our demands exceed its ability to deliver services. Internet and/cellular coverage is not up to expected level in many rural areas. Moreover whore there is coverage, the cost these services remains a barrier regardless of the innovations available. Despite the widely reported rapid growth of mobile network coverage the cost of a handy \& well featured handset and its utility is a thing of great concern.

b) Human Capacity: Illiteracy is a great problem among the rural peoples. ICT may make tools and information available but farmers must know that they exist and be capable to use them. Due to the illiteracy success of ICT innovation is greatly hampered.

c) Content: It ICT are to provide real decision tools it is necessary for an "ecosystem" of relevant information and data to exist. This short of information is under development in most of the cases. Information should be made and developed according to the need of end users (farmers) and provided in native language (Bangla), in simple interactive form. It must be up to date, relevant and supplied in a timely manner.

ICT is a tool for information generation and dissemination. ICT projects provide linkages enhance market access, develop business process and product diversity for the farmers. To monitor the impact of this tool we need to look into the most effective and successful ways to reach the farmers with timely and related information. More over there should be a better co-ordination among ASICT. BARI, MOA and other national bodies related to agriculture.

There must be multi focused approach by initiatives $\&$ innovations to meet the existing challenges and to cover up the needs of the end users (farmers). A comprehensive model is needed to address the limitations of existing methods and the feedback (from farmers) system to be developed to analysis the overall process.

ICT infrastructure thus can play the key role for the sustainable economic growth and can bring betterment to the agriculture \& the rural life as well.

\section{References}

Dash, P. and C. Kumar.2006. Prospects of e-agriculture in Bangladesh,e-Gov Asia.

Kashem, M. A, M. A. A Faroque, G. M. F. Ahmed and S. E. Bilkis. 2010. The complementary roles of information and communication technology Bangladesh agriculture J. Sci. Foundation. 8(1\&2): 161-169.

Malone, P., S, U. Akbar, M. Bell. 2012. Report on the Status of ICT for Agricultural Extension in Bangladesh, Following the MEAS sponsored Workshop at Rigs Inn, Dhaka, on December 3, 2012

Qaisar, T. M, M. A Khan and S. Alom. 2011. Innovative agricultural information services by ICT project in India. Int. J. of Trade, Econ. and Finance. 2(4), 276-279. 